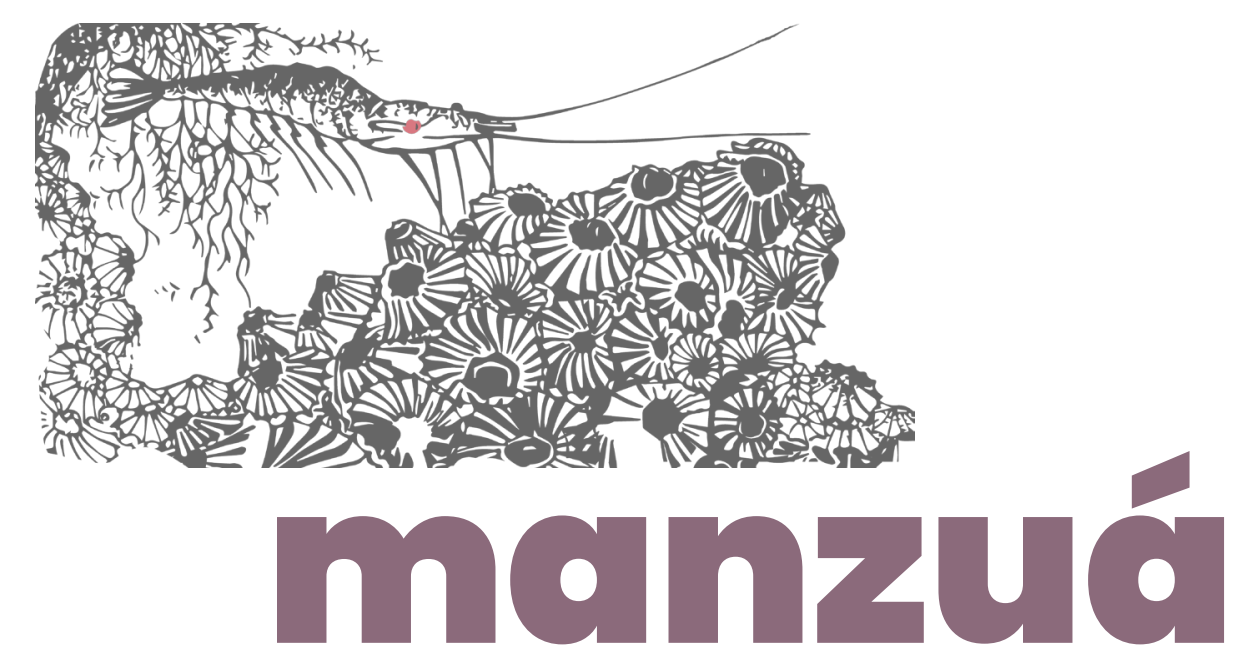

\title{
EXPERIÊNCIA CÊNICA E CULTURA DIGITAL POSSIBILIDADES TEATRAIS EM MEIOS VIRTUAIS
}

\section{RESUMO}

O texto apresenta reflexões sobre o universo da cultura digital e as possibilidades de criação e produção teatral mediadas pela tecnologia, a partir das experiências cênicas que surgiram no contexto pandêmico vivido no ano de 2020 pela disseminação do coronavírus. Com foco investigativo na experiência vivenciada com o experimento cênico-digital Enquanto a Festa não Chega, do Laboratório de Pesquisa e Criação Cênica - Cri'Ative'Se Lab. (Recife/PE). Caracteriza-se como uma pesquisa do tipo qualitativa, buscando um diálogo relacional entre o teatro e seus moldes já conhecidos, em interação com os meios virtuais. Utilizando como procedimento o estudo bibliográfico sobre cultura, cultura digital e as teatralidades contemporâneas; o recolhimento de discussões sobre o tema dispostos nas redes, o depoimento dos colegas participantes da experiência; e a análise das similaridades e diferenças com a hibridização dessas formas. Sob essa perspectiva, foi possivel identificar a capacidade transgressora do fazer teatral com uma nova percepção de presença, tempo e espaço - tão caros ao teatro -, a partir do estabelecimento de uma conexão diferenciada entre artistas e espectadores nas experiências mediadas pelos recursos tecnológicos. Surgindo assim, novas possibilidades e formas de criação e produção para o teatro.

Palavras-chave: Teatro. Digital. Cultura. Experiência 


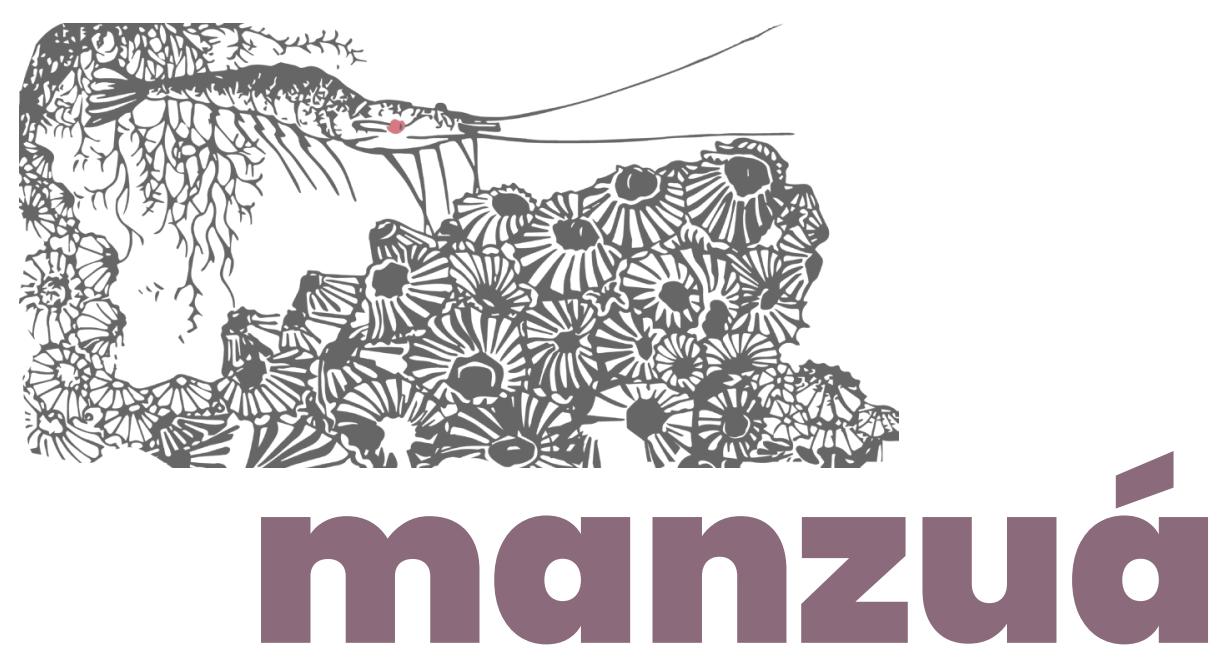

\begin{abstract}
The text presents reflections on the universe of digital culture and the possibilities of creation and theatrical production mediated by technology, based on the scenic experiences that emerged in the pandemic context experienced in the year 2020 by the spread of the coronavirus. With an investigative focus on the experience lived with the scenic-digital experiment Enquanto a Festa não Chega, from the Research and Scenic Creation Laboratory - Cri'Ative'Se Lab. (Recife/PE). It is characterized as a qualitative research, seeking a relational dialogue between the theater and its already known molds, in interaction with virtual media. Using as procedure the bibliographic study on culture, digital culture and contemporary theatricality; the gathering of discussions on the topic broadcasted on the networks; the testimonies of colleagues who participated in the experience; and the analysis of similarities and differences with the hybridization of these forms. From this perspective, it was possible to identify the transgressive capacity of doing theater with a new perception of presence, time and space - so dear to the theater -, from the establishment of a different connection between artists and spectators in the experiences mediated by technological resources. Thus appearing new possibilities and forms of creation and production for the theater.
\end{abstract}

Keywords: Theater. Digital. Culture. Experience. 


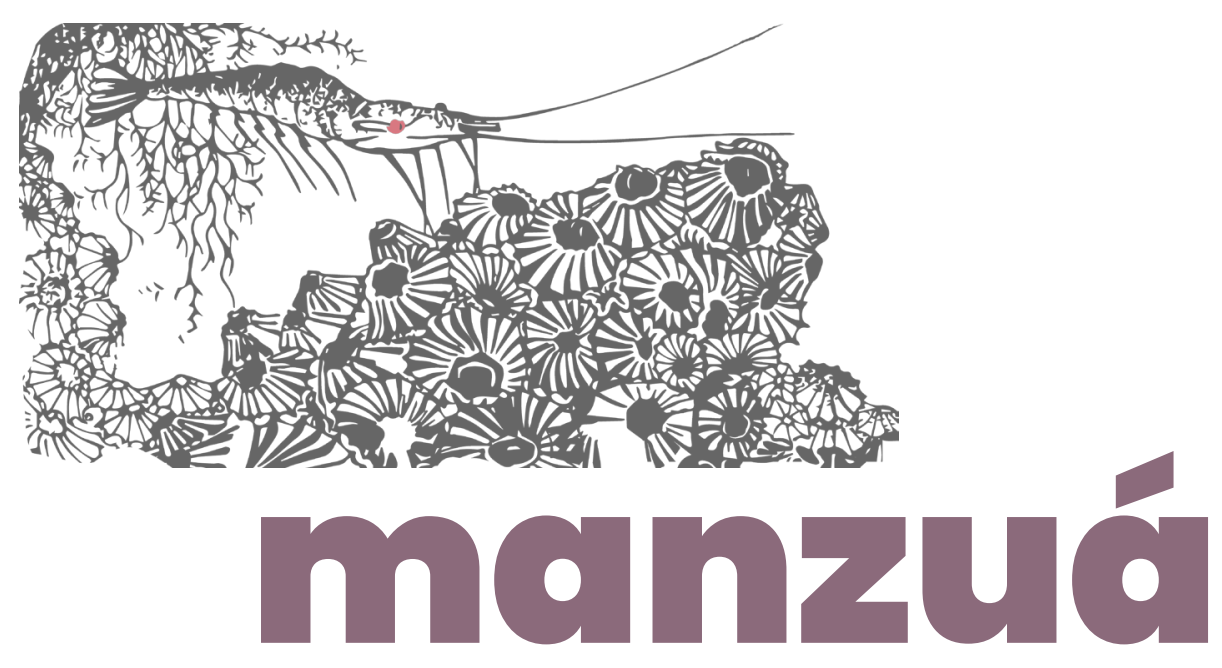

\section{Introdução}

No mundo globalizado, as plataformas digitais são importantes ferramentas de comunicação, tornando-se cada vez mais presente na vida das pessoas. Esse processo se deu a partir do advento da internet no final do século XX, ocasionando um expansivo alcance e consumo tecnológico, provocando mudanças histórico-culturais nos hábitos e práticas de interação da população em geral e nas mais diversas áreas, com o fenômeno da cultura digital. Permitindo momentos ficcionais de sociabilidade que por compartilhar de um determinado tempo e espaço se transformam em possibilidades reais de experiência. Uma experiência da virtualidade real.

Atualmente, nas artes da cena - mais especificamente no teatro -, esse fenômeno também tem promovido de forma gradativa uma desconstrução em relação ao entendimento de conceitos como tempo e espaço, viabilizando e transformando experiências que antes, necessariamente, precisavam dar-se in loco. Como é o caso dos diversos experimentos cênicos virtuais que estão surgindo com o momento de pandemia provocado pela disseminação do coronavírus no ano de 2020, encontrando possibilidades de uma presença virtual no real a partir da hibridização dessas formas.

De acordo com o Dicionário Etimológico (2008) do latim, cultura, culturae, significa "tratar", "cultivar" ou "cultivar a mente e os conhecimentos". Inicialmente a palavra culturae originou-se do termo latino colere, que quer dizer "cultivar as plantas" ou "ato de plantar e desenvolver atividades agrícolas", onde, posteriormente, surgiram analogias entre os cuidados agrícolas com o desenvolvimento das capacidades intelectuais do indivíduo.

Em suas pesquisas sobre as dimensões da cultura, segundo Botelho (2001, p. 74) "cultura é tudo o que o ser humano elabora e produz, simbólica e materialmente falando." Para a autora, a cultura 


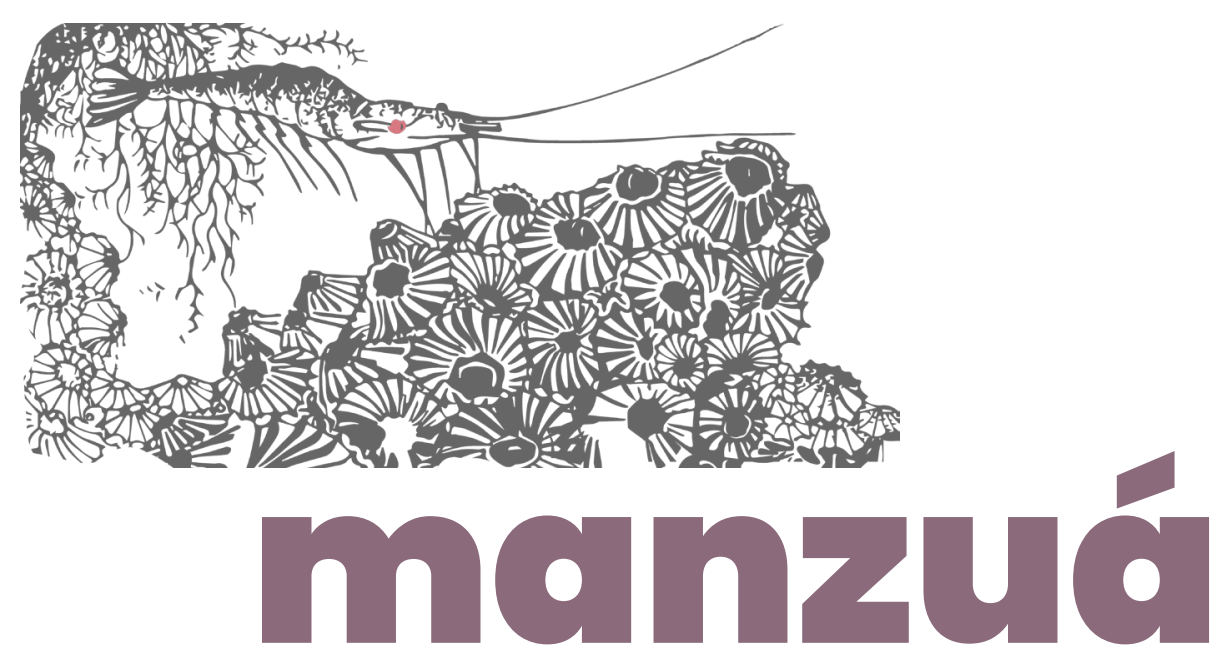

envolve, em diferentes dimensões - no antropológico e no social os hábitos, costumes, e as relações afetivas dos indivíduos, regendo suas ações em diferentes níveis.

Cabe, porém, ressaltarmos que diante da contemporaneidade existem diferentes conceitos de cultura estudados sob diversas ópticas: sociológica, antropológica, histórica, artística entre outras, que, por possuir características transversais, perpassa diferentes campos dos saberes e da vida desses seres. Sendo estes, influenciados pelo contato com as diversas ramificações culturais que surgem durante esse processo.

No final do século XX o avanço tecnológico possibilitou uma crescente globalização em diferentes aspectos, dentre eles, 0 cultural, iniciando assim, uma ramificação denominada como cultura digital. Como o nome sugere, faz parte dessa cultura as linguagens produzidas para os ciberespaços - ambiente virtual criado a partir dos meios de comunicação - com o intuito de integrar a realidade com o mundo virtual. Desse modo, tornou-se expansivo o alcance e consumo tecnológico que se deu principalmente a partir do advento da internet e suas infinitas possibilidades de ferramentas e plataformas que nos permeiam até os dias atuais.

Para o sociólogo Manuel Castells (2000) cultura digital é a habilidade de comunicar, produzir, mesclar e difundir qualquer produto baseado em uma linguagem digital. Esse tipo de cultura pode ser entendido como um conjunto de práticas e formas de interação mediadas pela tecnologia digital e demais ferramentas Tecnologias de Informação e Comunicação (TICs), que possibilite que essa interação flua de qualquer parte do mundo. Como no caso do uso dos computadores, buscas onlines, redes sociais e etc.

Para o sociólogo Pierre Lévy (1999) a inserção desses recursos tecnológicos gerou um fenômeno denominado como cibercultura, 


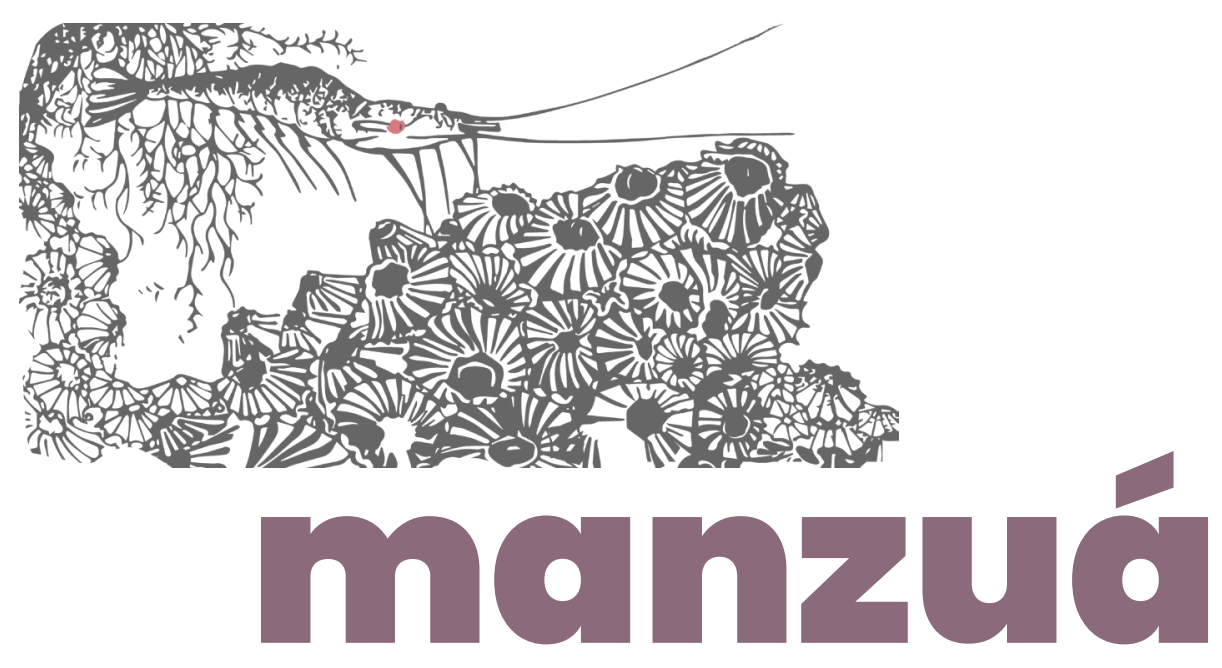

provocando novos hábitos, práticas e costumes no cotidiano dos indivíduos quando em contato com o virtual. O autor considera esse lugar virtual como ciberespaço, definindo-o "como o espaço da comunicação aberto pela interconexão mundial dos computadores e das memórias dos computadores". (1999, p. 92). Ou seja, o ciberespaço é uma estrutura de diálogo eletrônica que transmite informações de fontes digitais. Em paralelo, acompanha a cibercultura que pode ser definida como "o conjunto de técnicas (materiais e intelectuais), de práticas, de atitudes, de modos de pensamento e de valores que se desenvolvem juntamente com o crescimento do ciberespaço" (LÉVY, 1999, p. 17).

Com esse processo surge a cultura da virtualidade real. Para Manuel Castells (2000) não existe diferença entre o real e virtual, pois, a cultura consistiria no processo de comunicação baseado na produção e consumo de sinais contribuindo para o estabelecimento de uma experiência. Logo, o sistema digital gera uma virtualidade real na medida em que:

[..] A própria realidade (ou seja, a experiência simbólico/ material das pessoas) é inteiramente captada, totalmente imersa em uma composição de imagens virtuais no mundo do faz-de-conta, no qual as aparências não apenas se encontram na tela comunicadora da experiência, mas se transformam na experiência. (CASTELLS, 2000, p. 459).

Assim, esse sistema digital conseguiria invadir os espaços de sociabilidade com a experiência real que se cria nesse tempo e espaço por meio dessas comunidades/momentos ficcionais.

O ano de 2020, continuamente, nos dá indícios de que a linha tênue que poderia separar a realidade do virtual parece se 


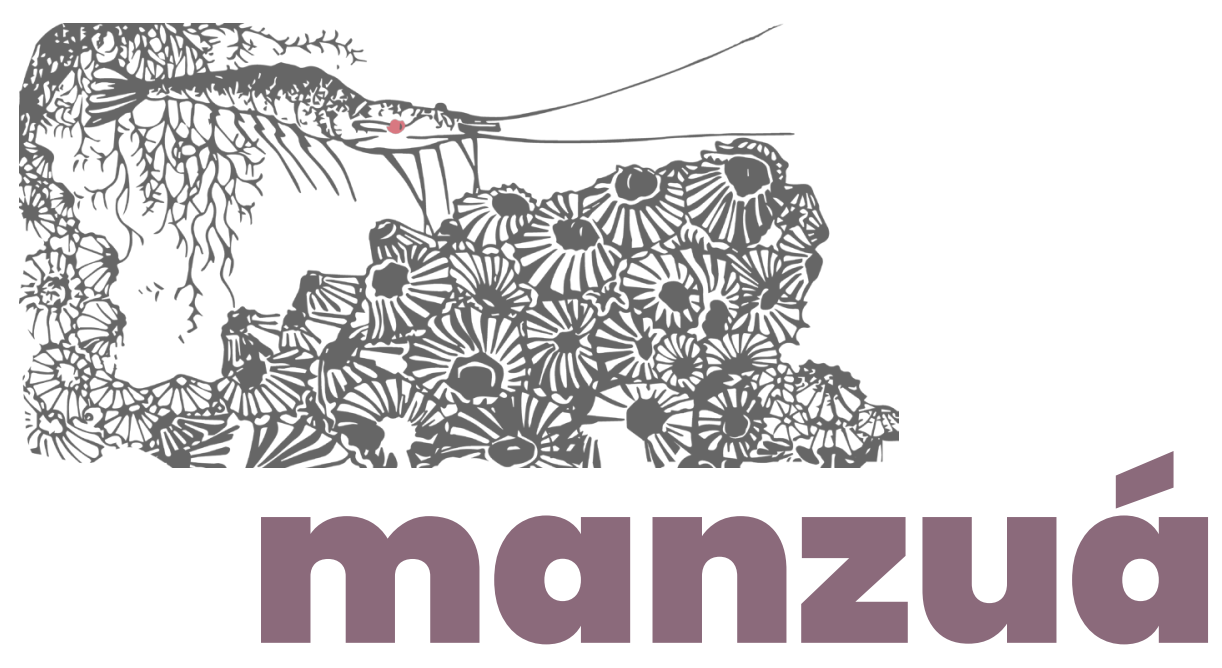

transcender: De acordo com a folha informativa da OPAS/OMS BRASIL, em 30 de janeiro de 2020, a Organização Mundial da Saúde (OMS) declara que o surto da doença causada pelo novo coronavírus se caracteriza como uma Emergência de Saúde Pública de Importância Internacional. Tornando-se em 11 de março de 2020 uma pandemia.

Não demorou muito para que, quase de modo ficcional - digno de um roteiro da Websérie -, todos os países do mundo fossem acometidos pela pandemia da Covid-19. Provocando uma mudança radical nos hábitos da população - que certamente terá sua trajetória influenciada por esse episódio -, a fim de alcançar um controle da disseminação da doença, ao colocar em cheque costumes cotidianos que precisarão adaptar-se a um novo "normal" adequados a recomendações sanitárias e de distanciamento social que de agora em diante, consequentemente farão parte de um marco histórico cultural.

Com o mundo paralisado, todas as formas de trabalho e em especial o setor cultural foi fortemente abalado - economicamente falando -, tendo em vista que, possivelmente será um dos últimos a retornar suas atividades pelo caráter de aglomeração das manifestações dos espaços culturais. Provocando assim, um cenário delicado, sobretudo para a comunidade artística ao considerarmos que essa área em específico é permeada pelo encontro entre a obra e o espectador.

A matéria da Folha de São Paulo, publicada em 03 de abril de 2020, intitulada "Impactos do coronavírus na cultura será de mais de R\$ 100 bilhões, diz especialista" prevê a fragilidade do setor frente à crise, estimando que "O prejuízo na área, que responde por 2,64\% do PIB brasileiro, pode ultrapassar os R $\$ 100$ bilhões". Em detrimento disso, instaura-se a "preocupação em impedir a falência das empresas do ramo" que mantém 5,2 milhões de pessoas, segundo o coordenador 


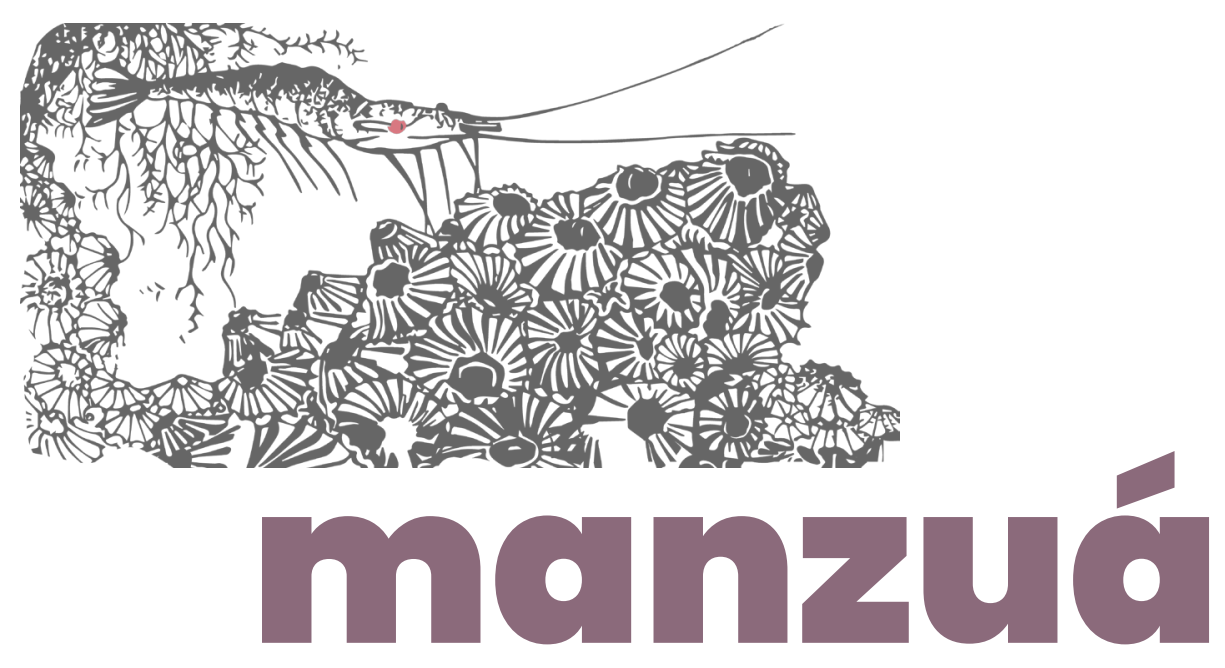

do Mestrado Profissional em Gestão da Economia Criativa da ESPM, João Luiz de Figueiredo, ao citar os dados do IBGE no ano de 2018. Isso se torna ainda mais delicado ao considerarmos que uma parte expressiva desses profissionais "trabalham por projeto" e "não têm vínculos formais de trabalho" também, segundo o especialista.

Artistas e trabalhadores da cultura em geral tiveram então que desenvolver soluções de criação e produção para manter sua sustentabilidade e a de seus grupos, e também, como forma de manter-se ativos em suas profissões. E com um mundo cada vez mais globalizado e virtualizado, que nos impulsiona a realidade da cibercultura, o uso dos ciberespaços, especificamente da internet, e a apropriação das ferramentas das redes tornou-se o principal meio para viabilizar o encurtamento da distância entre público e artistas. Iniciando assim, uma gama de experiências virtuais como shows, lives, exibição de filmes, peças de teatro e experimentos cênicos digitais diversos. Do qual, gostaria de refletir acerca das possibilidades teatrais para este último.

Neste artigo, pretende-se fazer algumas reflexões sobre 0 universo da cultura digital e sua relação com o acontecimento cênico quando mediado pelas tecnologias digitais. O objetivo dessa pesquisa é perceber as formas de interação desses dois mundos e identificar possibilidades para a criação e produção teatral a partir do relato de experiência do experimento cênico-digital Enquanto a Festa não Chega que surgiu com o momento de distanciamento social imposto pelo contexto pandêmico. Momento em que os artistas e trabalhadores da cultura em geral precisaram passar pela adaptação e/ou reinvenção de seus trabalhos, recorrendo aos recursos tecnológicos e sua capacidade de encurtar distâncias, como forma de continuar com as suas atividades. 


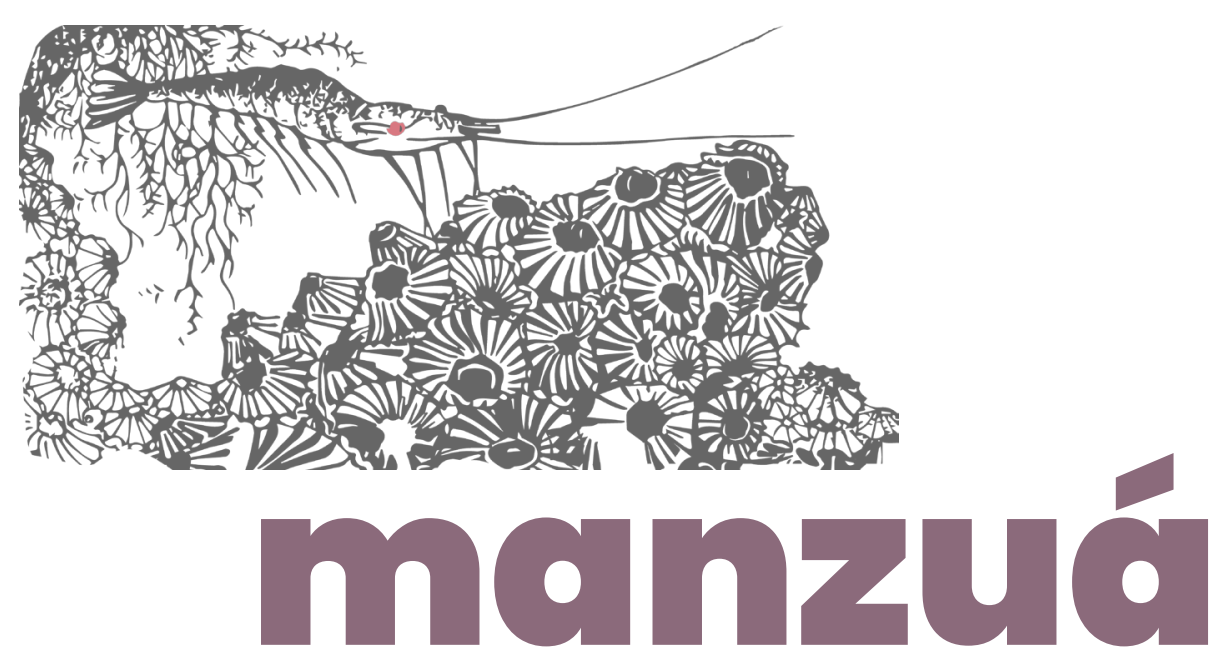

\section{Os ciberespaços e as possibilidades de criação e produção teatral na pandemia}

Sem previsão de retorno de suas atividades, os artistas da cena, em sua maioria trabalhadores autônomos que dependem do número de apresentações, do recolhimento da bilheteria e da presença do público para recepcionar suas obras, viram-se desempregados por meses a fio. E em meio ao distanciamento social, seria possível uma linguagem que tem como uma de suas principais características o encontro presencial do público e artista compartilhando um mesmo tempo e espaço sobreviver?

A situação pandêmica exigiu desses profissionais respostas estratégicas de enfrentamento a esse momento para além da recorrência a editais de apoio de iniciativa pública e privada, assim como a busca e compartilhamento de informações referentes às leis emergenciais para a cultura. A forma que esses artistas encontraram para continuar criando e produzindo seus trabalhos - por meio das plataformas digitais -, possibilitou um outro tipo de experiência para essa linguagem da qual ainda não estávamos acostumados: com o palco se transformando em plataformas como o Zoom, YouTube, Facebook e aplicativos como WhatsApp e Instagram, e com a relação público artista sendo mediada por uma tela.

Em entrevista concedida à Globonews, de título "Artistas migram dos palcos para a internet e descobrem novo público" publicado em 10 de agosto de 2020 no site do Gl da Globo, a atriz Ana Beatriz Nogueira fala sobre a necessidade de se reinventar com a adaptação de seus trabalhos para esse novo formato e identifica algumas características do fenômeno teatral que permanecem também na experiência virtual: 


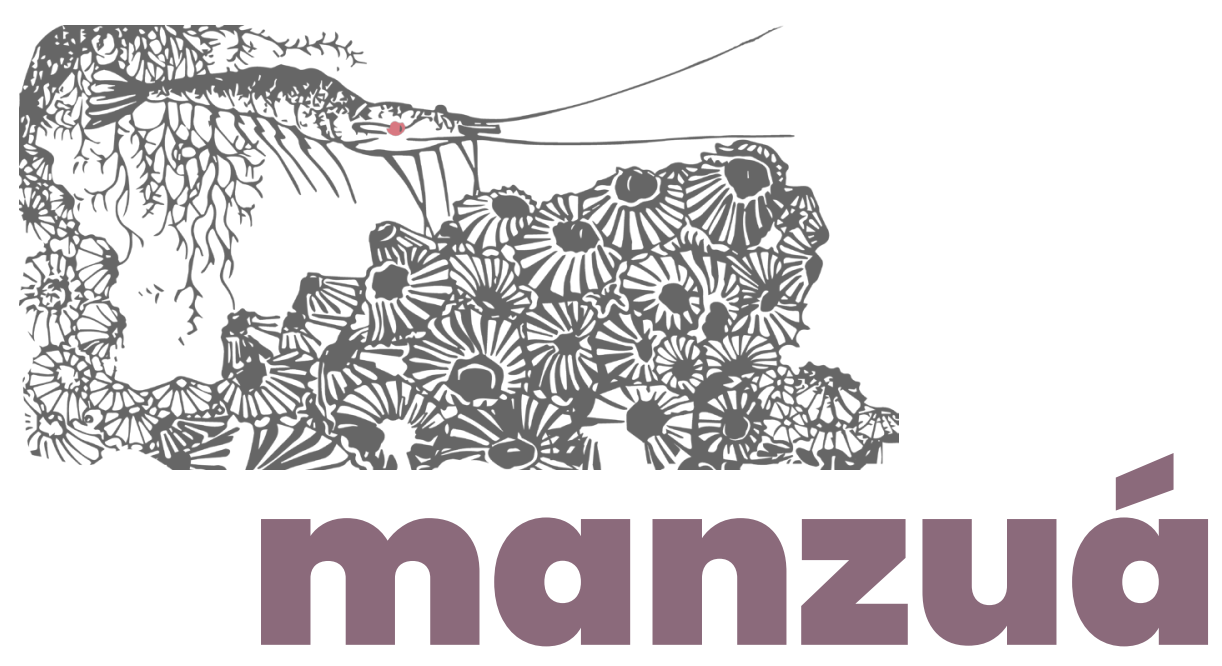

Eu vou fazer essa experiência na minha casa. Eu fiz um palquinho em casa [...] eu não tenho o tamanho do palco que eu tinha, então os movimentos são outros.... Eu nunca pensei na minha vida que para além de estrear uma peça, para além das borboletas no estômago de uma estreia, que eu fosse estar com outras borboletas pensando: a transmissão está boa? Está tudo sincronizado? [...] enquanto tiver alguém no palco e alguém na plateia, me desculpe, mas é teatro. (NOGUEIRA, 2020).

Já o ator e dramaturgo Giordano Castro, integrante do grupo Magitluh (Recife/PE) comentou em live de título "Teatro digital" realizada pelo canal do YouTube da Indelicada Cia Teatral (Goiânia/ GO) em 30 de agosto de 2020, que para eles, manter uma relação direta com o público, colocando-os como participantes da cena passeando pelos limites do até onde vai o real e começa o ficcional -, por meios das ferramentas corriqueiras de comunicação como WhatsApp, Instagram, E-mail e entre outros foi o caminho encontrado para manter em jogo as característica teatrais do grupo para a construção do trabalho denominado como um experimento sensorial em confinamento "Tudo que Coube numa VHS" e posteriormente "Todas as Histórias Possíveis".

Essa relação com o público é uma relação muito cara para a gente. [...] esse trabalho não se distancia de forma alguma da pesquisa que já era construída pelo Magiluth: A ideia da construção da atmosfera, da busca por criar um espaço de catarse. Uma forma possível de catarse entre o público e o trabalho. [...] tudo isso faz parte da construção do VHS. Sendo que o lugar de acontecer, é o lugar possível desse momento. (CASTRO, 2020). 


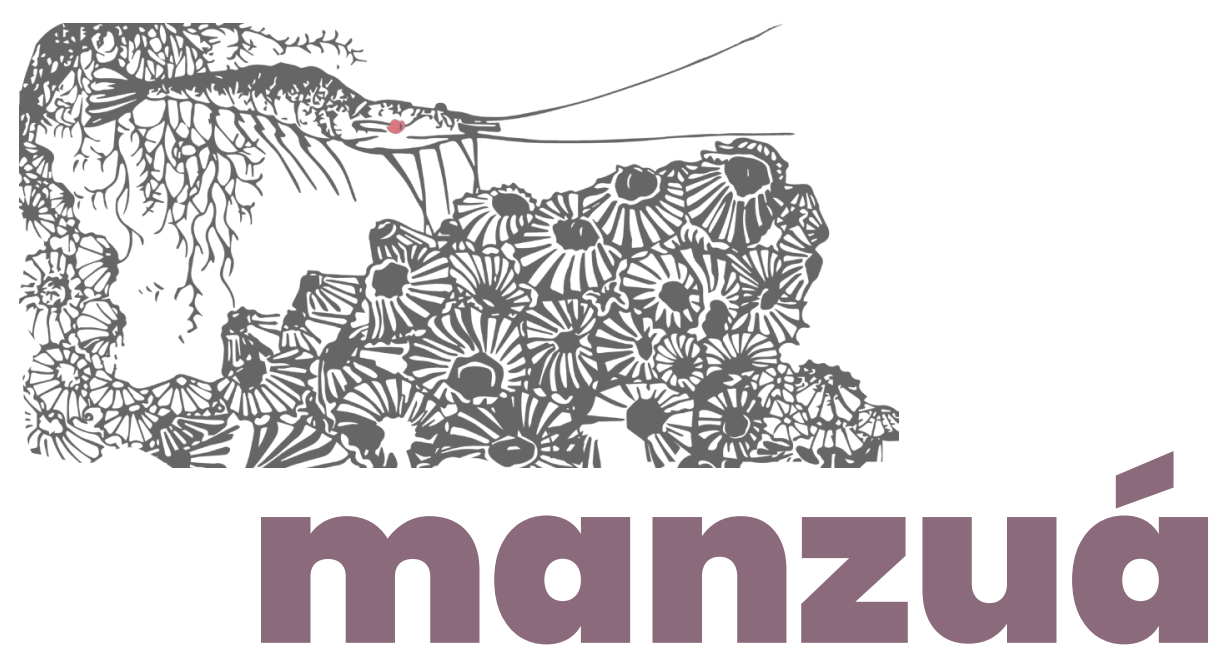

o uso de objetos cotidianos, o compartilhamento de momentos domésticos com situações familiares do grande público e a incerteza gerada pela possibilidade daquela narrativa ter sido gravada ou se tratar de fato de algo ao vivo contribui para a construção de uma experiência que mescla o real e o ficcional, estabelecendo uma atmosfera e possibilitando uma outra forma de conexão de tempo e espaço que não necessariamente precisa dar-se in loco.

- Mãe! O remédio da vovó! (Grita o ator Raphito Oliveira ao ter - ficcionalmente ou não - sua cena interrompida pelo som do despertador) quando minutos antes, o ligar da câmera revela em uma das cenas do Enquanto a Festa não Chega à intimidade de uma pessoa em confinamento realizando em seu quarto atividades que Ihe são rotineiras durante o período de quarentena.

Enquanto a Festa não Chega é um experimento cênico-digital com exibição pela plataforma Zoom, criado a partir do grupo de pesquisa sobre a mediação na relação público e artista do Laboratório de Pesquisa e Criação Cênica - Cri'Ative'Se Lab. (Recife/PE) do qual a autora desse texto pôde fazer parte na função de produtora pesquisadora.

O Cri'Ative'Se Lab. surgiu a partir da inquietação da professora - pesquisadora Emanuella de Jesus, mestre em Artes Cênicas pela Universidade Federal do Rio Grande do Norte - UFRN, que durante o período de distanciamento social com a interrupção do semestre letivo do Curso de Interpretação para Teatro - CIT, do Sesc Pernambuco, e consequentemente a suspensão da disciplina da qual lecionava na instituição, nos instigou a transformar a disciplina suspensa em um grupo de pesquisa. Com isso, surgiram quatro subgrupos: GT 1 - comunicação, GT2 - mediação na relação público artista, GT 3 - políticas públicas e estratégias de mecenato, e o GT 4 - 


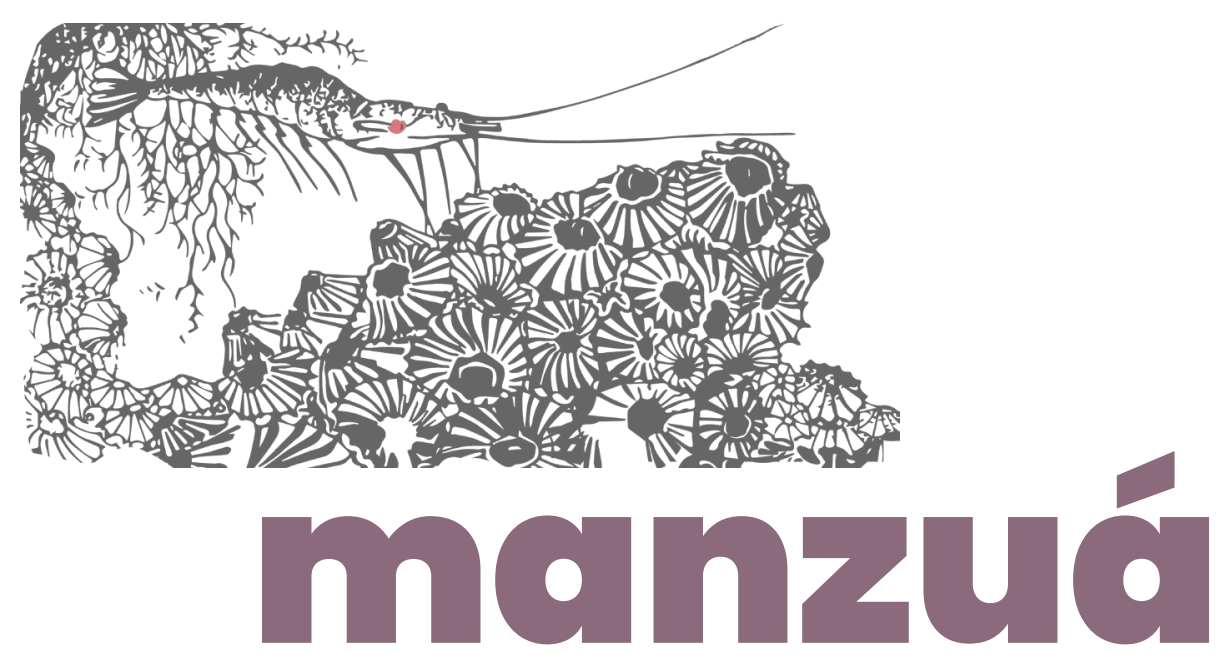

sustentabilidade ecológica e tecnologia. Tornando-se ao longo de 5 meses uma imersão em produção e criação cênica.

Fruto desse processo criativo, o Enquanto a Festa não Chega surge da necessidade dos artistas - pesquisadores envolvidos entenderem e compartilharem seus momentos de isolamento social e pela ânsia de um encontro onde fosse possivel festejar com seus pares novamente. Enxergando a experiência vivenciada por cada um desses artistas como um elemento em potencial para 0 acontecimento cênico, tendo em vista que, segundo Bondía (2002): "a experiência é o que nos passa, o que nos acontece, o que nos toca" e que o sujeito envolvido na experiência estaria como "um lugar de chegada, ou como o espaço do acontecer". (BONDíA, 2002, p. 24). Atravessados ainda, pelas seguintes provocações: quais as possibilidades de criação para o espaço virtual? $\mathrm{O}$ que tem de teatralidade na forma cotidiana da vida que podemos explorar para os meios digitais? E como se daria a relação público $x$ artista?

Ao pensarmos em Josette Féral, em suas pesquisas sobre a teatralidade na contemporaneidade, podemos perceber aspectos primordiais para esse acontecimento: "sua escritura cênica, sua relação com o corpo do performador, com o tempo de representação, com o real, com o espaço" (FÉRAL, 2015, p.136) ou seja, para a autora, a teatralidade se encontra também na vida - o real - e também no efeito extra cotidiano existente na intervenção sobre esse real por intermédio da obra artística. Esse foi um eixo primordial para que buscássemos uma teatralidade da vida cotidiana que estivesse em diálogo com seus performers e com o tempo e espaço onde vivem.

Com o processo investigativo, reconhecemos a efemeridade como um fenômeno inerente ao fazer teatral, tendo em vista que, a experiência vivenciada nos acontecimentos cênicos é capaz de ficar 


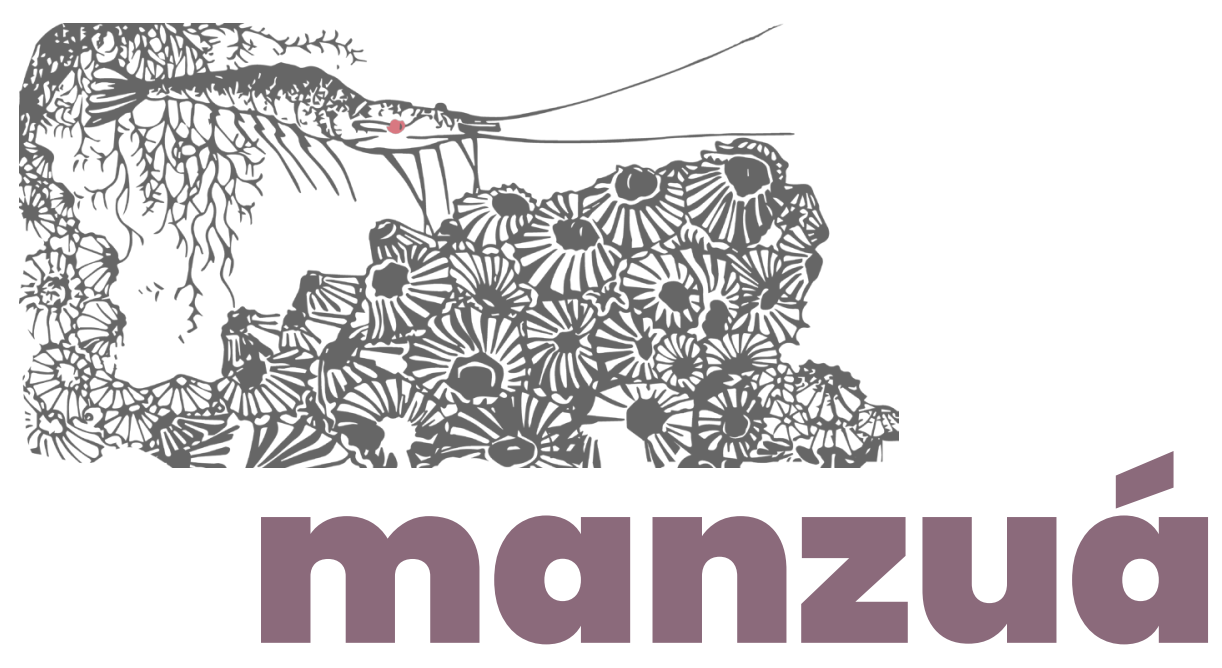

gravada apenas na retina e memória de quem o faz e quem assiste. Em outras palavras, o teatro em seus moldes já conhecidos seria a arte do aqui e agora. A tentativa de preservar essa essência foi o fator determinante para que o trabalho fosse realizado em livestreaming.

Ao longo da temporada em livestreaming pelo Zoom, os momentos pré-espetáculo, que antigamente se davam nos camarins, é substituído agora pelos ajustes na plataforma. É preciso desligar o microfone e as coxias se transformam nas câmeras também desligadas.

Do lado de cá, dos bastidores, é possivel perceber os atores se descobrindo quanto às possibilidades de atuação: é preciso dialogar com os ângulos e enquadramentos necessários a tela. Os movimentos se adaptam para caber nesse espaço. A expressividade também passa pelo direcionamento da atenção quanto à ênfase dada às intenções das personagens. Essas nuances chegam para nós agora a partir do jogo entre os diferentes modos de exibição do layout da tela.

Passa a ser função dos atores também, operar a iluminação, a sonoplastia, e fazer o trabalho de contrarregragem necessários para cada cena. Logo, as luzes de led, caixinhas de som e a utilização dos objetos de uso cotidiano, se tornam elementos cênicos que, somados ao trabalho de atuação contribui para a construção de uma atmosfera intimista na cena, quando o uso dos refletores e outros aparatos disponíveis nos espaços físicos dos teatros já não estão presentes, agora no ambiente doméstico. Essas são as possibilidades de teatralidade que enxergamos como existentes na vida cotidiana. 


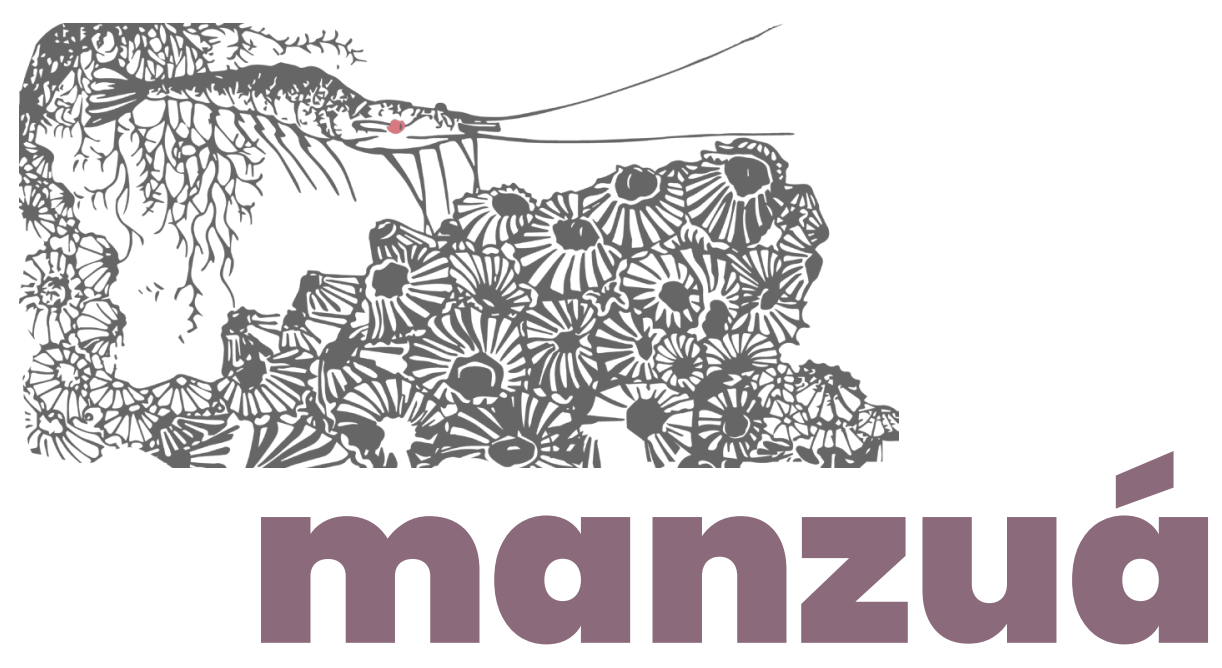

\section{Experiências das etapas metodológicas de produção}

Também fez parte dessa investigação as possibilidades de produção para esse novo formato. Aos poucos, questões de ordem práticas foram surgindo: Qual plataforma iríamos utilizar para a execução do experimento cênico-digital? Como seria o acesso do público? Como aconteceria a venda dos ingressos e quais as formas de divulgação? Com isso, algumas etapas metodológicas delinearamse durante esse percurso, e o uso das ferramentas tecnológicas de comunicação foi o principal veículo que encontramos para viabilizar esse processo. Como explanado abaixo:

\begin{tabular}{|c|c|c|c|c|c|}
\hline \multicolumn{2}{|r|}{ ETAPAS } & AÇÕES DESENVOLVIDAS & MAI & JUN & JUL \\
\hline $1^{a}$ & Planejamento & $\begin{array}{l}\text { Reuniões e escolha das plataformas e } \\
\text { aplicativos }\end{array}$ & $x$ & & \\
\hline $2^{a}$ & Execução & $\begin{array}{l}\text { Criação do evento na plataforma escolhi- } \\
\text { da e venda dos ingressos }\end{array}$ & & $x$ & $x$ \\
\hline $3^{a}$ & Divulgação & $\begin{array}{l}\text { Confecção de folders; gravação de vídeos } \\
\text { e publicação nas redes }\end{array}$ & $x$ & $\mathrm{x}$ & $x$ \\
\hline $4^{a}$ & Temporada & $\begin{array}{l}\text { Ensaios na plataforma e apresentações } \\
\text { em livestreaming }\end{array}$ & $\mathrm{x}$ & $\mathrm{x}$ & $\mathrm{x}$ \\
\hline $5^{a}$ & Pós-produção & $\begin{array}{l}\text { Reuniões, relatórios, prestação de contas } \\
\text { e considerações sobre o evento }\end{array}$ & & & $x$ \\
\hline
\end{tabular}

Na primeira etapa ocorreram reuniões de planejamento que aconteciam pelo aplicativo Google meet para elencarmos quais as possibilidades dispostas no momento para atender nossas expectativas. O uso de algumas plataformas online pode ser uma das alternativas disponíveis para a realização de eventos e disponibilização 


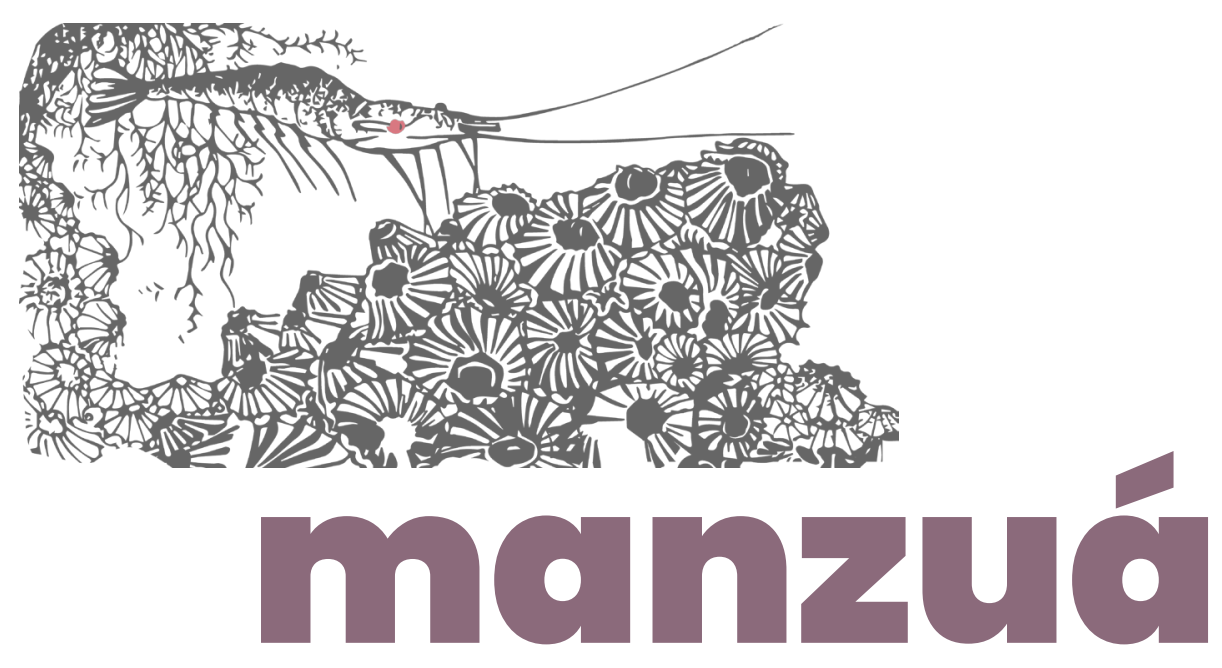

de ingressos quando não se pode ter acesso aos teatros e as bilheterias físicas desse espaço. O Sympla Streaming (beta) em integração com a plataforma Zoom foi o meio que utilizamos para realizar de forma remota uma temporada com cinco apresentações, e também, para disponibilizar os ingressos para o público.

Com a segunda etapa criou-se o evento na plataforma Sympla e iniciou-se a venda dos ingressos com o acompanhamento em tempo real da disponibilidade destes para cada sessão. Foi durante esse período também, com essa ferramenta, que recolhíamos informações de contato WhatsApp dos participantes que eram fornecidos por meio de formulário no ato da compra, e que posteriormente, seria usado para iniciarmos o contato.

Para a etapa de divulgação, foi preciso investirmos em algumas estratégias como a confecção de folders, vídeos e publicações dispostos semanalmente em redes sociais como Instagram e Facebook em dias e horários programados levando em consideração pesquisas prévias sobre as estatísticas de engajamento para as redes.

A quarta etapa foi o momento em que o experimento cênico - digital esteve em temporada em livestreaming com cinco apresentações nos finais de semana de junho e julho. Precedendo essas apresentações, eram realizados ensaios na plataforma com o elenco, direção e a equipe de produção. E nos dias anteriores a cada apresentação, para o contato com o público, o uso do aplicativo WhatsApp foi necessário para o envio de mensagens com as instruções de participação. Era intuito nosso, além de fornecer as informações de acesso, conduzi-los a um clima festivo ao marcarmos nosso encontro com cada espectador solicitando que se preparassem como de costume para uma festa. Nessa etapa 


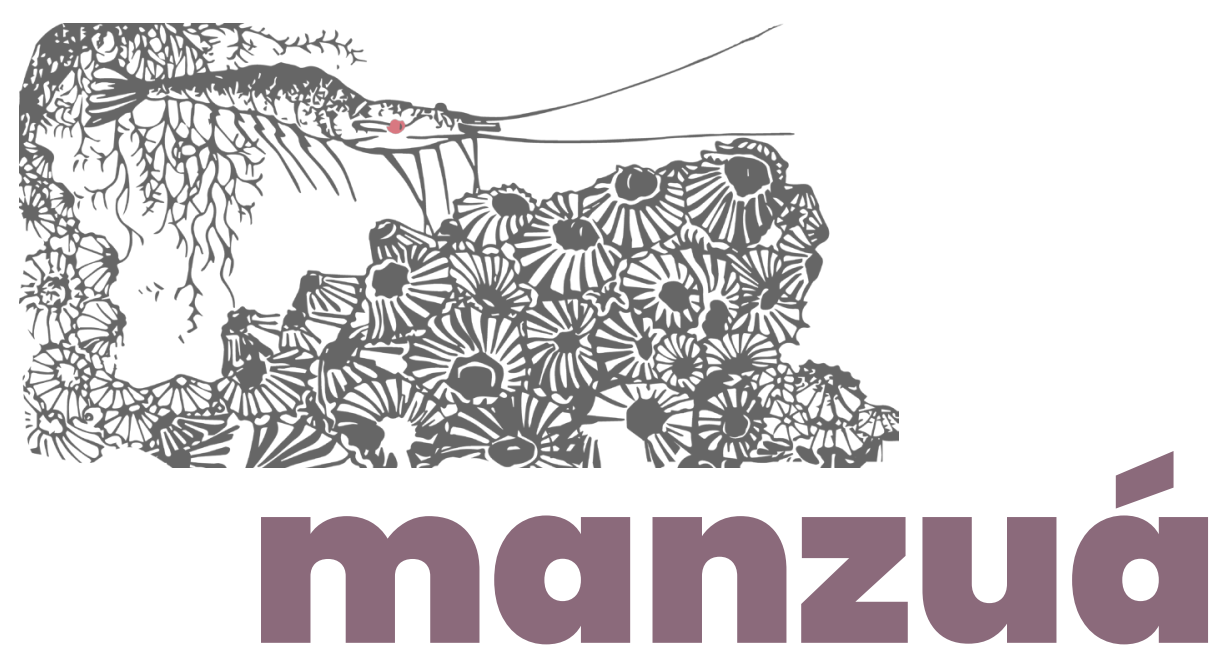

realizávamos também, reuniões avaliativas semanais pelo Google meet, considerando o andamento das apresentações: o que estava funcionando bem, sinalizar o que poderia ser ajustado e perceber e atender outras expectativas que surgiam com o decorrer do evento.

A quinta e última etapa foi a da pós-produção. Com o fim da temporada, ocorreram encontros para considerações finais, desenvolvimento de relatórios, recolhimento da bilheteria e distribuição desta entre a equipe envolvida, e também a prestação de contas.

Esse foi o modo que encontramos para tornar esse festejar virtual em uma experiência real ao estabelecermos com o público uma outra forma de conexão de tempo e espaço na medida em que compartilhávamos de um ato extra cotidiano para o momento de isolamento social: o marcar um encontro, separar uma roupa, se arrumar, pegar uma bebida e encontrar os amigos para se divertir e dançar.

\section{Relação público $x$ artista}

O abrir das cortinas é substituído agora pelo ligar das câmeras no horário marcado, e apesar de estarmos separados - fisicamente falando - a possibilidade de nos vermos pela tela do computador ou celular e dividirmos um mesmo espaço virtual nos traz a sensação de proximidade. Ainda existe uma relação que é permeada pelo encontro entre a obra e o espectador. E consequentemente, a suspensão momentânea do cotidiano que se dá pelo envolvimento com os acontecimentos teatrais. Como comenta o ator, dramaturgo e arteeducador Rodrigo Hermínio em vídeo publicado em 22 de junho de 2020 no Instagram do O Cinematólogo, relatando sua experiência ao presenciar o Enquanto a Festa não Chega: 


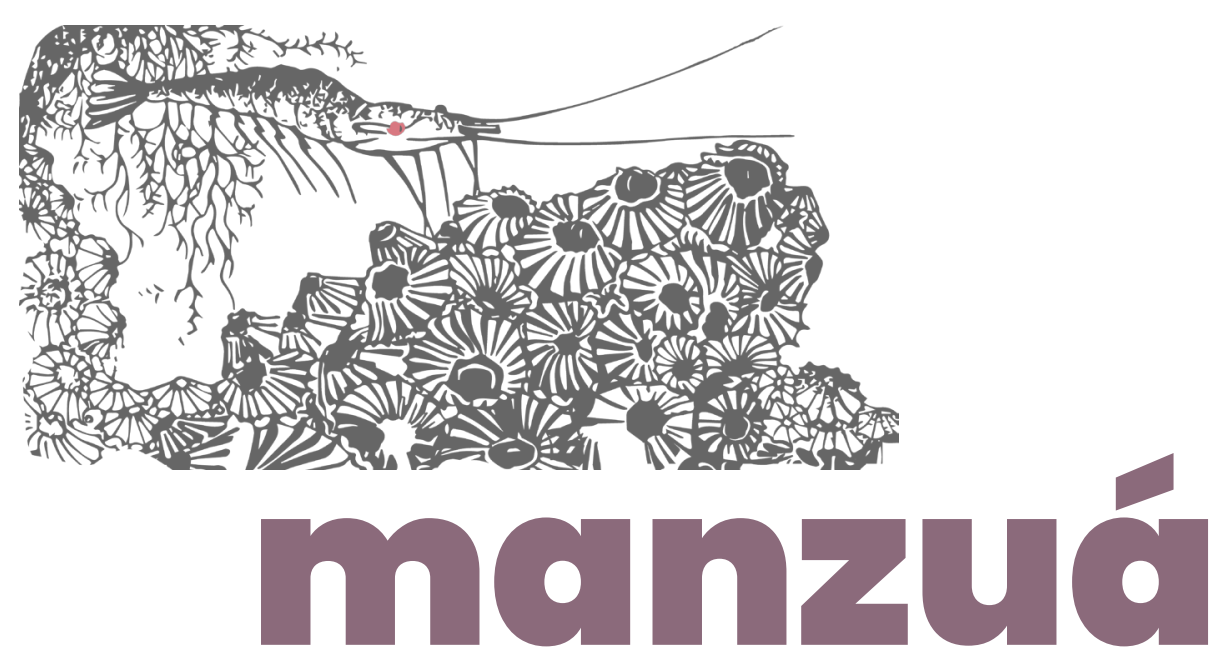

É muito interessante você entrar nesse ambiente virtual, ver pessoas dentro de casa, em um momento de quarentena, em um isolamento social vestidas, maquiadas, usando uma roupa para sair; coisa que a gente não faz há mais de 100 dias. E a gente pode durante alguns momentos viver essa realidade. [...] o Enquanto a Festa não Chega é isso: É a gente pensar como seria fazer esse teatro durante a pandemia, pensar como é esse encontro, essa dualidade de público e atores/atrizes. (HERMÍNIO, 2020).

Com a entrada do público no ambiente virtual, acontecia um momento de mediação pré-espetáculo iniciado através de mensagens instantâneas via chat, ingressando uma conversa descontraída - típica de um encontro inicial entre amigos -, sobre como os participantes estavam e o que andavam fazendo durante o correr dos dias. Seguida da aparição de um mediador para dar continuidade a conversa e passar as instruções de uso da plataforma Zoom para o início do espetáculo.

Para esse formato, estar aberto a adaptações e manter uma relação de interação com os espectadores e com os recursos disponíveis para o momento pode ser uma alternativa de aproximação entre público e artista para esse novo encontro. Seja por meio das trocas de mensagens instantâneas via chat ou colocando os espectadores como personagens ativos na cena. Para esse último, com o correr do experimento cênico-digital, existia um momento em que esse fator se dava de forma efetiva, com o público sendo convidado a ligar suas câmeras e adentrar na cena para dar palpites referentes à qual combinação de roupas o personagem do ator Danilo Ribeiro deveria usar para ir à festa. Abaixo, o ator comenta com foi a experiência da relação com o público: 


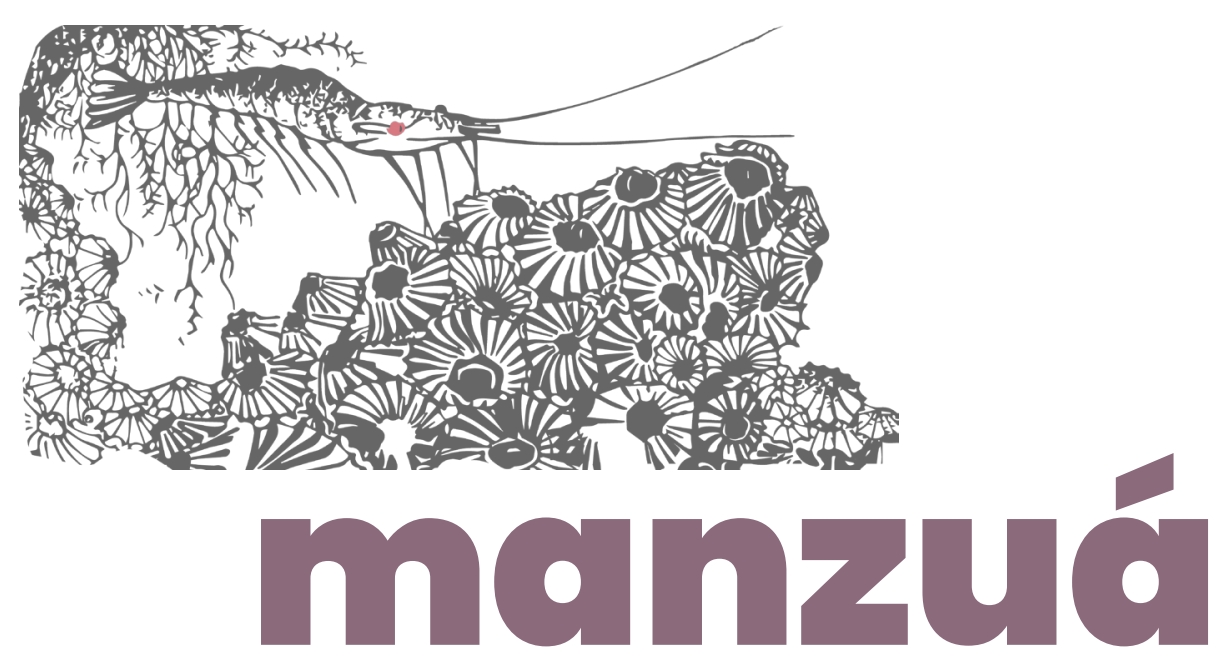

Eu me diverti bastante porque minha cena tinha uma coisa de improvisação, então, eu nunca sabia o que ia acontecer. [...] eu tinha um planejamento, eu tinha aqueles elementos de cena que ia usar, mas dependendo do público tudo se modificava [...] acho que o que teve de instigante para trabalhar no Enquanto a Festa não Chega foi essa coisa da imprevisibilidade. Tanto da minha cena, quanto a de todos os fatores [tecnológicos] novos. (RIBEIRO, 2020).

É possível perceber que, dentro dos aspectos levantados anteriormente, houve similaridades e diferenças entre o teatro em seus moldes já conhecidos e sua mutação para os meios virtuais. Inevitavelmente, parece ocorrer um hibridismo com o audiovisual se considerarmos algumas características próprias dessa linguagem como por exemplo a necessidade de adequação aos ângulos e enquadramentos da câmera em diálogo com características teatrais como as nuances da expressividade dos intérpretes, os elementos visuais e a harmonia desses com a encenação. E consequentemente as funções desempenhadas pelos profissionais do teatro também passaram por adaptações - todos permeados pela tecnologia-, em um momento que nossa realidade de encontro e convivência se dá unicamente de forma virtual.

Sob essa conjuntura, o experimento cênico-digital Enquanto a Festa não Chega foi o modo que encontramos para nos mantermos ativos em nossos estudos e ofício ao termos nossas atividades paralisadas em meio ao momento de distanciamento social provocado pela disseminação do coronavírus. Não é objetivo desta pesquisa definir se essas experiências cênicas em voga no momento são ou não teatro, mas sim, de investigar possibilidades teatrais dentro de suas similaridades e diferenças -, no espaço possível para que essa manifestação artística acontecesse nesse momento. 


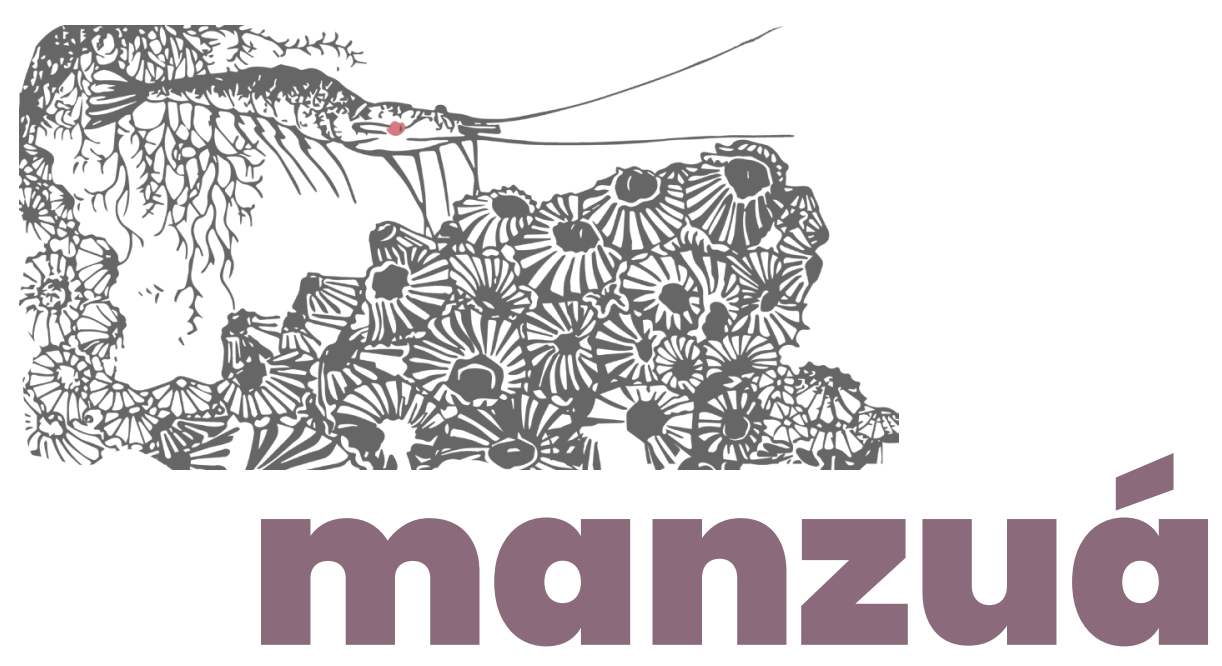

É fato que a arte teatral assumiu uma forma diferenciada para os meios digitais, mas se observamos atentamente, há uma característica de mutação em curso em sua história: como arte milenar, inevitavelmente, o teatro esteve em diálogo com seu tempo assumindo novas vertentes e estéticas, mas nunca deixou de existir. Podemos perceber essa característica desde as manifestações ritualísticas iniciais destinadas ao deus Dionísio; com as representações pautadas no texto e o surgimento do Deus ex machina - expressão grega designada para dar fim a narrativa com a aparição de um personagem inesperado -, na antiguidade; com a evolução dos espetáculos teatrais resultado da revolução tecnológica com a descoberta dos recursos de iluminação elétrica e com o advento do encenador na modernidade; e mais adiante, com as encenações centradas na performidade do ator e as teatralidades plurais que surgem com a contemporaneidade. E paralelo a isso, com a utilização de recursos midiáticos e a construção de espetáculos que mesclam diversas formas artísticas com o uso das tecnologias em cena, com o teatro pós-dramático, nas últimas décadas do século XX. Como comenta o jornalista, professor e pesquisador Leonardo Folleto ao citar esse período:

O teatro até então essencialmente "dramático", baseado no texto, cede terreno à imagem, ao uso de tecnologias midiáticas e digitais e a incorporação de referências explícitas de áreas como a dança, as artes visuais, o cinema e a performance. (FOLETTO, 2011, p. 47).

Como isso, podemos perceber ainda, que o teatro esteve em diálogo com seu tempo aproveitando as novas tecnologias de modo imediato, possibilitando novas formas ao fazer teatral. 


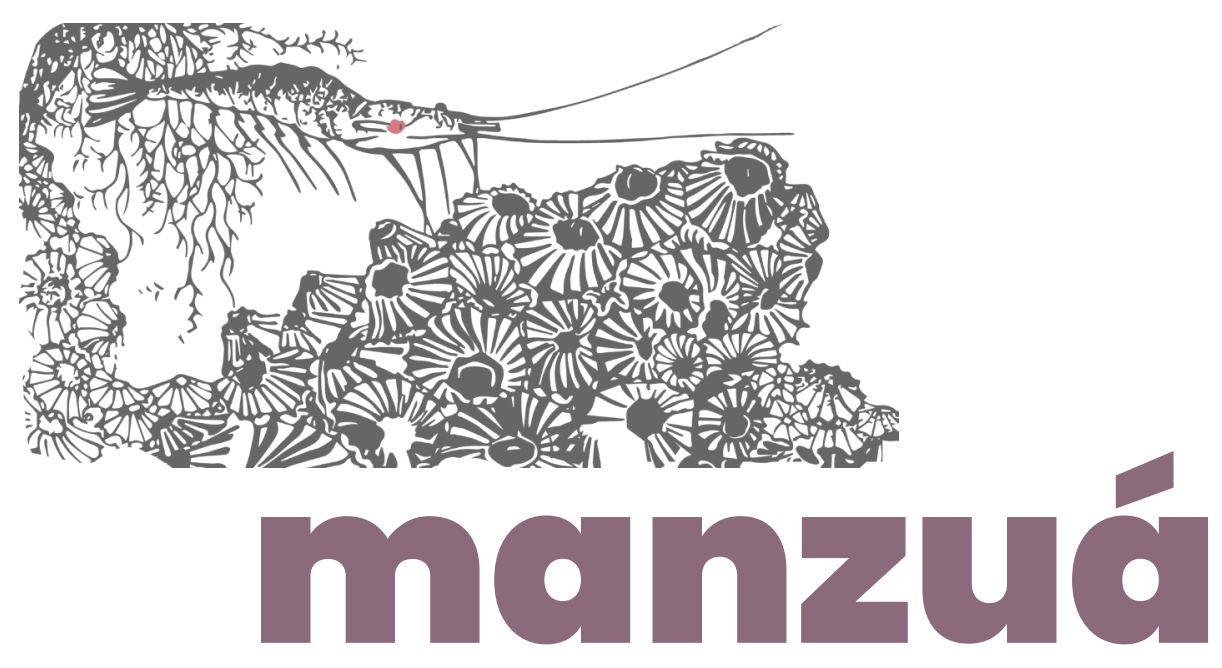

E com o momento pandêmico vivido no ano de 2020 provocado pela disseminação da Covid-19, o teatro precisou reformular-se ou adaptar-se mais uma vez, migrando para os meios digitais. Desse modo, as invenções e apropriações tecnológicas atuais não impedem as práticas já existentes, mas corroboram com elas, encontrando novas formas de continuar expressando as experiências humanas. E enquanto o Deus ex machina com sua capacidade de resolver tudo em um piscar de olhos - não importa qual forma ficcional e absurda a narrativa assuma -, não se encontra como um recurso disponível a ser utilizado na realidade, é necessário que, nós artistas da cena, lancemos mão da adaptabilidade e reinvenção para nos mantermos ativos em nossas profissões e não sucumbirmos diante de um cenário de insegurança trazido pela proliferação de um vírus avassalador que nos seria impeditivo.

Essa nova forma é teatro? É possível preservar sua essência com essa prática? Estaríamos nos encaminhando para o descobrimento de um novo fazer teatral? Provavelmente seguiremos sem respostas para essas questões por mais algum tempo, mas talvez, esse seja o momento de refletirmos sobre quais as possibilidades para o teatro com as formas que estão surgindo e como podemos utilizá-las a nosso favor daqui em diante, ao invés de nos apegarmos ao que estaríamos perdendo com esse processo, pois certamente, a arte tem como uma de suas características principais o transgredir-se. 


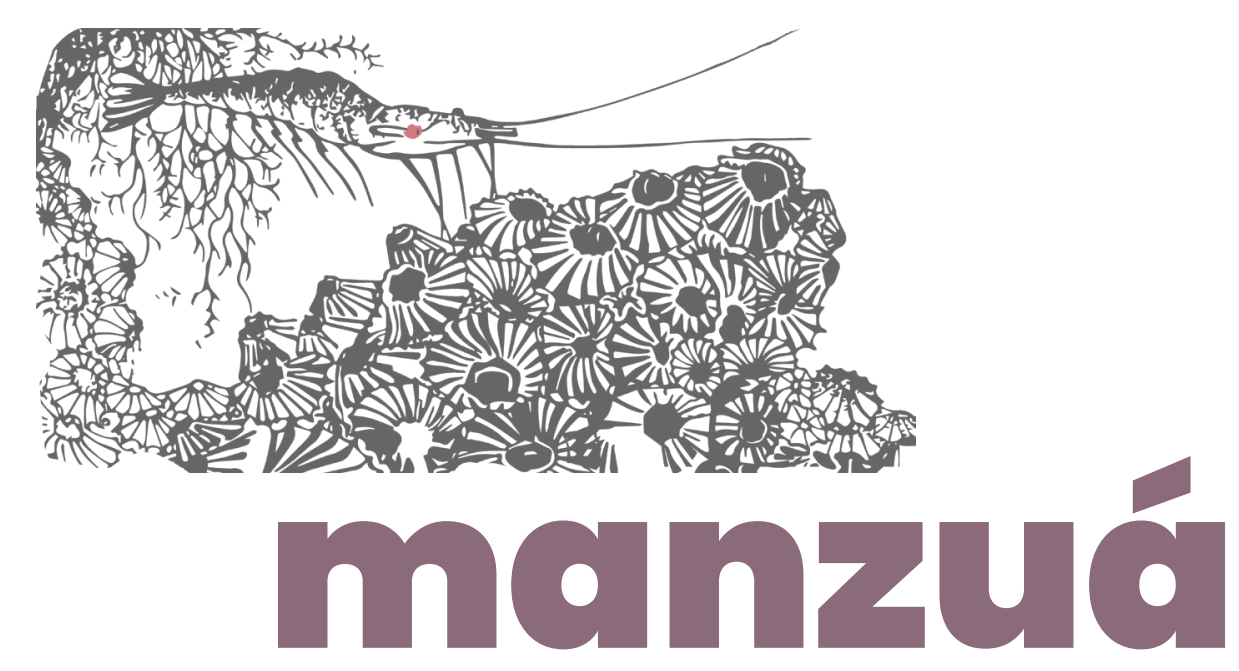

\section{Referências bibliográficas}

BALBI, Clara. Impacto do coronavírus na cultura será de mais de R\$ 100 bilhões, diz especialista. Folha de São Paulo, 03 de abril de 2020. Disponível em: https://wwwl.folha.uol.com.br/ilustrada/2020/04/ impacto-do-coronavirus-na-cultura-sera-de-mais-de-r-100bilhoes-diz-especialista. Acesso em: 04 set. 2020.

BONDIA, Jorge Larrosa. Notas sobre a experiência e o saber de experiência. Rev. Bras. Educ., Rio de Janeiro, n. 19, p. 20-28, abr. 2002. BOTELHO, Isaura. Dimensões da Cultura e Políticas Públicas. São Paulo em Perspectiva. São Paulo, v.15, n.2, p. 73-83, abr. 2001. Disponível em: http://www.scielo.br/scielo.php?script=sci_arttext\&pid=s0102$88392001000200011 \&$ Ing=pt\&nrm=iso. Acesso em: 05 set. 2020.

CASTELLS, M. A sociedade em rede. 8. ed. Rio de Janeiro: Paz \& Terra, 2000.

COMPANHIA INDELICADA TEATRAL. Live indelicada com Giordano Castro sobre "Teatro Digital". 1 vídeo (57min). Disponível em: https://www. youtube.com/watch?v=lylKgYiNq38\&feature=youtu.be. Acesso em: 19 set. 2020.

CULTURA. In: Dicionário Etimológico. Porto: 7 Graus, 2020. Disponível em: https://www.dicionarioetimologico.com.br/cultura/. Acesso em: 30 ago. 2020.

FÉRAL, Josette. Além dos limites: teoria e prática do teatro. São Paulo: Perspectiva, 2015.

FOLETTO, Leonardo. Efêmero Revisitado: Conversas sobre Teatro e Cultura Digital. Santa Maria: Baixa Cultura, 2011. Disponível em: http:// www.articaonline.com/wp-content/uploads/2013/06/EfemeroRevisitado-Conversas-sobre-teatro-e-cultura-digital.pdf. Acesso em: 03 out. 2020.

HERMÍNIO, Rodrigo. Crítica (Teatro) - Enquanto a festa não chega. Instagram: @ocinematologo, 22 de jun. de 2020. Disponivel em: https:// www.instagram.com/tv/CBuQurLnJ9X/. Acesso em: 22 jun. 2020.

LÉVY, Pierre. Cibercultura. São Paulo: Editora 34, 1999.

NOGUEIRA, Ana Beatriz. Artistas migram dos palcos para internet e descobrem novo público. Globonews, 10 de ago. de 2020. Rio de Janeiro. Disponível em: http://gl.globo.com/globo-news/videos/v/ artistas-migram-dos-palcos-para-internet-e-descobrem-novo- 


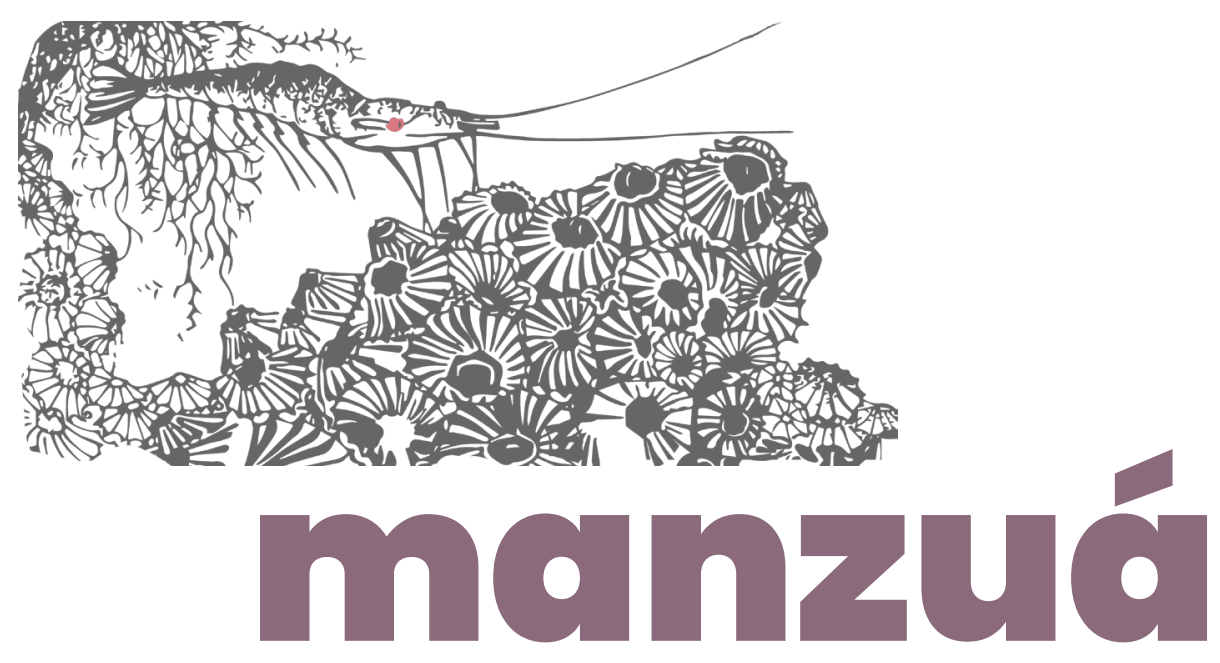

publico/. Acesso em: 06 set. 2020.

ORGANIZAÇÃO PAN-AMERICANA DE SAÚDE (OPAS). OMS declara emergência de saúde pública de importância internacional por surto do novo coronavírus. Opas Brasil, 2020. Disponível em: $\quad$ https://www.paho.org/bra/index.php?option=com content\&view $=$ article\&id $=6100$ :oms-declara-emergencia-desaude-publica-de-importancia-internacional-em-relacao-a-novocoronavirus. Acesso em: 01 set. 2020. 